\title{
PENGARUH PENATAAN MASSA BANGUNAN TERHADAP POLA AKTIVITAS SANTRI (STUDI KASUS PONDOK PESANTREN ISLAMIC CENTRE BIN BAZ PUTRA YOGYAKARTA)
}

Farah Fauzan Azhima

Program Studi Arsitektur Fakultas Teknik Universitas Muhammadiyah Surakarta

e-mail : azahiema@gmail.com

\section{Rini Hidayati}

Program Studi Arsitektur Fakultas Teknik Universitas Muhammadiyah Surakarta e-mail :rh215@ums.ac.id

\begin{abstract}
ABSTRAK
Kebutuhan utama manusia ada 3 yaitu sandang, pangan, dan papan. Papan (bangunan) dengan kehidupan manusia tidak dapat dipisahkan, karena manusia pasti melakukan aktivitas di dalam bangunan. Kenyamanan pada bangunan dapat terealisasi jika pada proses merancang telah memperhatikan segala segi seperti pola masa bangunan atau ruang, serta pola pergerakan manusia. Salah satu objek yang dapat kita amati yang di dalamnya terdapat hubungan antara tata massa bangunan, sirkulasi, dan pola pergerakan aktivitas adalah pondok pesantren. Pondok pesantren yang akan diteliti adalah Pondok Pesantren Islamic Centre Bin Baz Yogyakarta (Ponpes ICBB). Ponpes ICBB memiliki dua komplek pesantren yang terpisah yaitu komplek ikhwan (putra) dan akhwat (putri) sehingga untuk kemudahan dan efisiensi penelitian ini difokuskan pada komplek Ponpes ICBB putra dengan permasalahan yang diangkat adalah pengaruh penataan massa bangunan Ponpes ICBB Putra terhadap pola aktivitas santri. Penelitian ini menggunakan metode kualitatif. Peneliti melakukan observasi terhadap objek penelitian untuk mendapatkan data baik data fisik maupun non fisik. Kemudian data yang diperoleh akan dianalisis dengan melihat kesesuaianya terhadap skema awal perencanaan aktivitas santri berdasarkan jadwal yang telah diatur oleh pengelola pondok pesantren. Hasil penelitian adalah bahwa tata massa bangunan mempengaruhi pola pergerakan aktivitas santri untuk mencari jalur pergerakan/sirkulasi yang paling nyaman, dengan kriteria jalur bersih, lebih terbuka, sekalipun jalur sirkulasi itu lebih lama sampai di tempat tujuan. Dalam kasus ini dapat diidentifikasi bahwa pola tata massa Ponpes ICBB putra kurang efisien, sehingga santri harus beradaptasi dengan mencari cara beraktivitas yang efisien menurut mereka.
\end{abstract}

KATA KUNCI: aktifitas; bangunan; pondok pesantren; santri; tata masa

\section{PENDAHULUAN}

Kebutuhan utama manusia ada 3 yaitu sandang, pangan, dan papan atau bangunan. Bangunan dan kehidupan manusia tidak dapat terpisahkan, karena manusia sebagai makhluk hidup pasti melakukan aktivitas atau kegiatan. Aktivitas harus terwadahi dalam suatu tempat atau bangunan. Kenyamanan tempat atau bangunan menjadi tuntutan dari aktivitas.

Kenyamanan pada bangunan dapat terealisasi jika pada proses merancang telah memperhatikan segala segi seperti pola sirkulasi, bangunan dan lingkungan. Pola berkaitan dengan tata letak massa bangunan dan pergerakan manusianya. Penataan massa bangunan ini sangatlah penting, karena berhubungan dengan sirkulasi yang terbentuk dari tatanan massa yang ada. Sirkulasi adalah jalur yang difungsikan untuk mencapai suatu bangunan baik menggunakan atau tanpa alat bantu seperti kendaraan. Oleh sebab itu menjadi suatu keharusan sirkulasi mampu menghadirkan kenyamanan bagi yang menggunakanya.

Salah satu objek yang dapat diamati, yang di dalamnya terdapat hubungan yang kompleks antara tata massa bangunan, sirkulasi, dan pola pergerakan aktivitas manusia adalah pondok pesantren. Pondok pesantren yang akan diteliti adalah Pondok Pesantren Islamic Centre Bin Baz Yogyakarta (Ponpes ICBB). Ponpes ICBB memiliki dua komplek pesantren yang terpisah yaitu komplek ikhwan (putra) dan akhwat (putri). Penelitian ini difokuskan pada komplek Ponpes ICBB putra, dengan pertimbangan ponpes putra memiliki jumlah bangunan yang lebih banyak dan lebih kompleks fungsinya daripada bangunan di ponpes putri. Selain itu jumlah santri, pengelola lebih banyak. Keadaan ini sesuai dengan tujuan penelitian, yaitu untuk mengidentifikasi pengaruh penataan masa bangunan terhadap pola aktivitas santri dalam memenuhi kebutuhan santri. 


\section{TINJAUAN PUSTAKA}

\section{Pola Masa Bangunan}

Pola adalah suatu yang menjelaskan gambaran/ pengelolaan struktural mendasar yang termasuk di dalamnya penataletakan massa, baik itu bangunan maupun lingkungan, yang menghasilkan suatu ikatan keseimbangan dan keselarasan. Berdasarkan jenisnya pola massa bangunan dapat dibagi menjadi 6 jenis, yaitu (Yadnya dalam Iswara, 2014) : monolit, kompak, linier, grid, cluster, dan memusat. Pengembangan konsep bentuk dan pola massa bangunan pada tapak harus memenuhi kriteria sebagaimana berikut:

1. Mampu menghadirkan fungsi bangunan yang sesuai dengan tapak.

2. Teori-teori arah pandang.

3. Teori-teori keindahan berupa ritme, presure, balance, proporsi dan skala.

Pengambangan bentuk dasar massa bisa dilakukan dengan beberapa metode, yaitu:

1. Menyatukan kedua bentuk dasar massa baik persegi, lingkaran, dan segitiga.

2. Menggabungkan kedua bentuk dasar atau lebih dengan menambahkan atau menguranginya.

\section{Sirkulasi}

Sirkulasi adalah pola peredaran yang terdapat dalam suatu zona atau massa. Sirkulasi di dalam suatu bangunan hendaknya dapat memberikan fleksibilitas, pertimbangan ekonomis, dan fungsional (Haris dalam Iswara, 2014). Sistem sirkulasi adalah prasarana penghubung vital yang menghubungkan segala aktivitas dan pemanfaatan suatu tapak di atas suatu zona dan di dalam massa yang memperhatikan segi fungsional, ekonomis, fleksibilitas dan kenyamanan. Berdasarkan fungsinya sirkulasi dapat dibagi menjadi 3 yaitu:

1. Sirkulasi Manusia

2. Sirkulasi Kendaraan

3. Sirkulasi Barang

Tujuan dari sitem sirkulasi ada dua yaitu:

1. Bermaksud tertentu dan memiliki arah pandang ke tempat tujuan, memiliki sifat langsung (direct). Pengguna berkeinginan perjalanan dalam sistem ini akan lebih singkat dan cepat dengan jarak sedekat mungkin.

2. Memiliki sifat hiburan dengan waktu yang tidak terbatas. Hal yang diutamakan dalam sirkulasi adalah kenyamanan.

Dalam membuat suatu sistem sirkulasi pada massa ada beberapa hal yang menjadi pertimbangan, yaitu:

1. Segi keindahan yang bisa menciptakan rasa emosional.

2. Perencanaan yang lebih baik pada tingkat keamanannya.
3. Kesan keindahan pertama yang didapatkan pada daerah sirkulasi sangat berpengaruh terhadap massa secara keseluruhan.

4. Pola sirkulasi yang efisien untuk ukuran ruang, skala monumental, terbuka dan estetis secara visual.

5. Pola sirkulasi harus memberikan kejelasan tanpa harus ada tanda-tanda pengarah orang berjalan.

6. Pencapaian ke dalam hall yang luas dan menarik dengan melalui sebuah pintu yang tinggi mampu memberikan kesan terkesima.

7. Bentuk pola sirkulasi linier, radial, grid, organic, sesuai bentuk tata masa bangunan.

\section{Perilaku}

Setiap manusia memerlukan ruang yang bersifat personal, dengan batasan yang tidak tampak dan batasan itu ada di sekitar seseorang. Ruang personal membuat orang lain tidak boleh memasukinya atau enggan untuk memasukinya. Ruang personal ini akan menjaga seseorang berada dalam zona nyaman. Ruang personal ini dapat pula terbentuk disebabkan posisi seseorang dalam sebuah setting, baik posisi seseorang terhadap orang lain ataupun seseorang dengan lingkungan sekitar. Setiap manusia membutuhkan adanya interaksi dengan sesama manusia atau dengan lingkungan. Interaksi antara suatu kegiatan dengan tempat yang spesifik disebut sebagai behavior setting.

Pembahasan tentang behavior setting umumnya berkaitan dengan perilaku-perilaku secara konstan atau berkala pada suatu setting tertentu. Perilakuperilaku tersebut akan membentuk pola yang khas dan terkadang tidak kasat mata, sehingga memerlukan upaya penggalian dan interpretasi yang dapat mengungkapkan penyebab terjadinya pola perilaku sebagai bagian dari kekayaan dan kedalaman penelitian.

Behavior setting mengandung unsur; 1) sistem setting berupa rangkaian unsur fisik atau spasial yang memiliki hubungan tertentu dan terkait dengan suatu kegiatan, dan 2) sistem aktifitas berupa sistem kegiatan atau rangkaian perilaku yang dilakukan oleh seseorang atau beberapa orang (Hariyadi, 2010). Setiap setting harus sesuai dengan kebutuhan manusia dalam melakukan aktifitasnya. Aktifitas manusia sebagai wujud perilakunya akan mempengaruhi dan dipengaruhi oleh tatanan atau setting fisik dalam sebuah ruang, sehingga untuk memenuhinya dibutuhkan adanya kenyamanan, aksesibilitas, legibilitas, kontrol, terirorialitas dan keamaanan.

\section{METODE PENELITIAN}


Penelitian ini menggunakan metode penelitian kualitatif. Peneliti melakukan observasi terhadap objek penelitian untuk mendapatkan data. Kemudian data yang telah diperoleh akan dianalisis dengan melihat kesesuaianya terhadap skema awal perencanaan aktivitas santri berdasarkan jadwal yang telah diatur oleh pengelola pondok pesantren.

Penjelasan singkat proses penelitian sebagai berikut:

1) Tahap pertama, kajian pustaka dan menyusun kerangka pikir dan metode penelitian

2) Tahap kedua, tinjauan langsung ke Ponpes ICBB putra untuk pendataan melalui observasi dan wawancara

3) Tahap ketiga, rekonstruksi pola masa bangunan dan sirkulasi ke dalam gambar berdasarkan data dalam bentuk iso-activity

4) Tahap keempat, analisi iso-activity dengan melihat kesesuaian skema awal perencanaan aktivitas santri berdasarkan jadwal yang sudah diatur oleh pengelola pondok pesantren.

Fokus penelitian adalah Pengkajian pola aktivitas santri Ponpes ICBB putra baik santri dari jenjang Madrasah 'Aliyah (MA) maupun Salafiyah Wustha (SW) yang dipengaruhi oleh penataan massa bangunan ponpes tersebut. Santri yang akan diamati aktivitasnya difokuskan kepada santri yang menempati asrama dengan jarak terjauh dari pusat pengamatan.

Variabel pada penelitian ini adalah sebagai berikut :

1. Variabel Bebas

Variabel bebas adalah variabel yang mempengaruhi variabel lainya. Variabel bebas pada penelitian ini adalah setting atau tata massa bangunan Ponpes ICBB putra.

2. Variabel Terikat

Variabel terikat adalah variabel yang dipengaruhi variabel lainya. Variabel terikat pada penelitian ini adalah pola aktivitas santri yang dipengaruhi oleh setting ponpes.

Teknik pengumpulan data menggunakan teknik observasi, studi literature dan wawancara. Analisis data menggunakan metode kualitatif deskriptif. Analisis ini berisi penjelasan peneliti yang ditunjang oleh skema pola aktivitas santri yang terbentuk dari penataan massa bangunan Ponpes ICBB Putra Yogyakarta.

\section{HASIL DAN PEMBAHASAN}

Komplek Ponpes ICBB putra beralamatkan di Jl. Wonosari KM. 10, Karanggayam, Sitimulyo, Piyungan, Bantul, D.I. Yogyakarta 55792. Luas komplek Ponpes ICBB Putra Yogyakarta kurang lebih $20.987 \mathrm{~m}^{2}$.

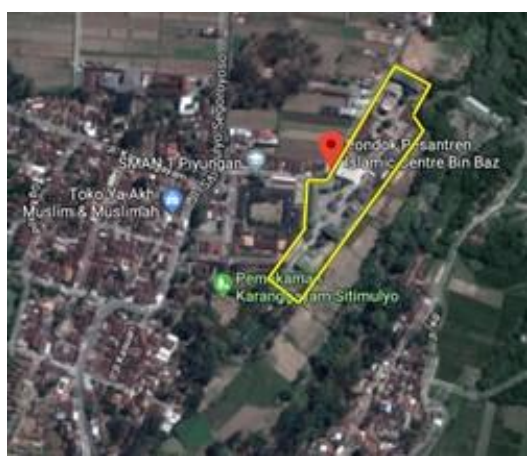

Gambar 1. Lokasi Komplek Ponpes ICBB Putra Yogyakarta (Sumber : https://www.google.com/

maps/place/Pondok+Pesantren+|slamic+Centre+Bin+Baz/

Jumlah santri putra dari jenjang SW sampai MA yang menempati komplek tersebut kurang lebih ada 800 santri dengan jumlah santri MA 400 orang dan santri SW 400 orang. Selain para santri, para ustadz, pengajar, dan pengelola beserta keluarganya pun juga menghuni komplek Ponpes ICBB putra ini, karena di komplek ini selain bangunan asrama, ada juga bangunan perumahan ustadz dan karyawan pondok pesantren.

Pola tata massa bangunan yang diterapkan pada Ponpes ICBB putra adalah pola tata massa linier.

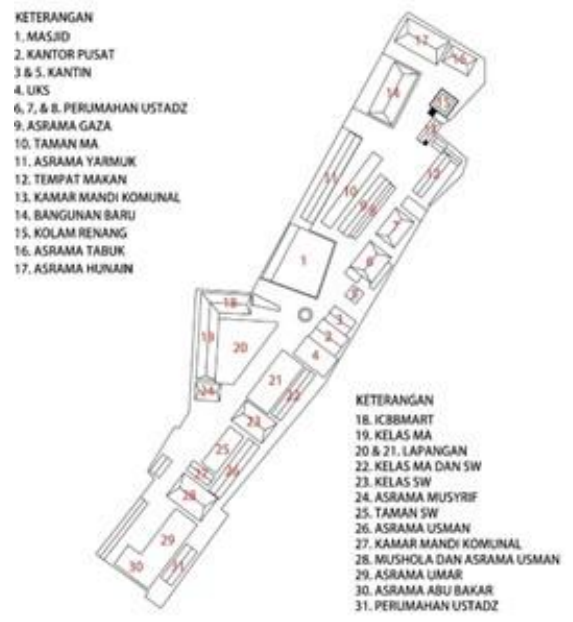

Gambar 2. Siteplan Pola Tata Massa Bangunan dan Keterangan Fungsinya (Sumber : Dokumen Peneliti, 2018)

Aktivitas santri dari bangun tidur hingga istirahat malam atau tidur lagi dilakukan di dalam komplek Ponpes. Setiap aktivitas atau kegiatan santri sudah diatur oleh pengelola Ponpes sesuai jamnya masingmasing sebagaimana yang tertera pada tabel berikut :

Table 1. Kegiatan Santri Ponpes ICBB Putra Yogyakarta

\begin{tabular}{c|l}
\hline \multicolumn{1}{c|}{ Jam } & \multicolumn{1}{c}{ Kegiatan } \\
\hline 03.00-04.00 & $\begin{array}{l}\text { Bangun tidur dan persiapan sholat } \\
\text { subuh }\end{array}$ \\
\hline 04.00-06.00 & $\begin{array}{l}\text { Sholat subuh kemudian Halaqoh } \\
\text { Tahfizh Al Qur'an }\end{array}$ \\
\hline
\end{tabular}




\begin{tabular}{|c|c|}
\hline $06.00-07.00$ & $\begin{array}{l}\text { Sarapan pagi dan persiapan } \\
\text { sekolah }\end{array}$ \\
\hline $07.15-10.10$ & Waktu KBM \\
\hline $10.10-10.45$ & Istirahat sekolah \\
\hline $10.45-12.30$ & Waktu KBM \\
\hline $12.30-13.00$ & Sholat dzuhur \\
\hline $13.00-14.00$ & Makan siang \\
\hline $14.00-14.45$ & Tidur siang \\
\hline $14.45-16.15$ & $\begin{array}{l}\text { Sholat ashar kemudian Halaqoh } \\
\text { Tahfizh Al Qur'an }\end{array}$ \\
\hline $16.15-16.30$ & $\begin{array}{l}\text { Kegiatan sore (bebas) dan olahraga } \\
\text { Makan malam dan mandi }\end{array}$ \\
\hline $16.30-17.30$ & Sholat maghrib kemudian Halaqoh \\
\hline $17.30-19.00$ & Tahfizh Al Qur'an \\
\hline $19.00-20.45$ & $\begin{array}{l}\text { Sholat 'isya kemudian belajar } \\
\text { malam }\end{array}$ \\
\hline $20.45-22.00$ & $\begin{array}{l}\text { Kegiatan malam (bebas) kemudian } \\
\text { tidur malam }\end{array}$ \\
\hline
\end{tabular}

(Sumber : Dokumen Peneliti, 2018)

Pengamatan dimulai dari santri bangun tidur kemudian keluar asrama menuju masjid untuk melaksanakan sholat subuh. Santri bangun pukul 03.00-04.00 WIB. Pada waktu ini yang peneliti amati adalah aktivitas santri dari asrama hunain menuju masjid. Pada skema awal perencanaanya, pengelola mengatur santri ketika menuju masjid adalah melalui jalur depan asrama Gaza, dengan pertimbangan jalur sirkulasi tersebut adalah yang paling singkat (efisien).

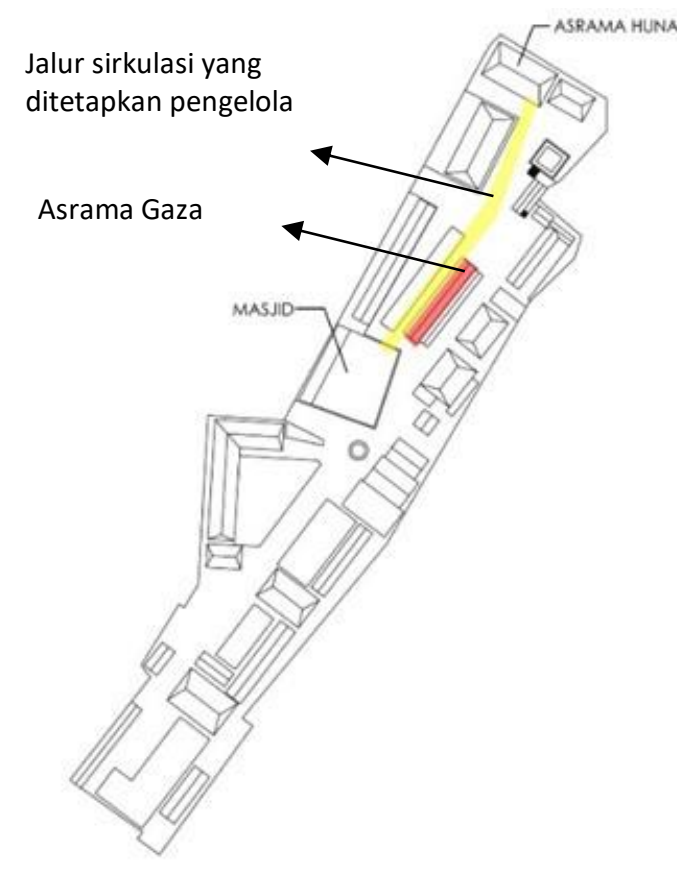

Gambar 3. Jalur sirkulasi yang ditetapkan

(Sumber : analisis peneliti, 2018)

Namun pada saat pengamatan, peneliti menemukan ada sebagian santri ketika berangkat ke masjid tidak melalui jalur depan asrama Gaza, melainkan melalui jalur lain. Jalur yang digunakan sebagian santri tersebut adalah jalur depan perumahan ustadz.

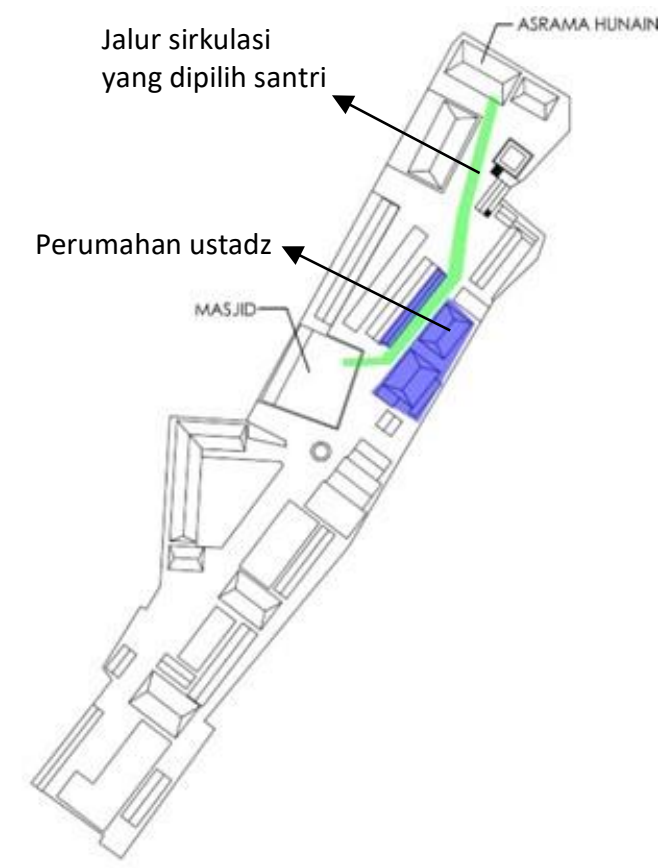

Gambar 4. Jalur sirkulasi yang dipilih santri

(Sumber : analisis peneliti, 2018)

Pengamatan terhadap perubahan jalur sirkulasi, dimana jalur yang sudah ditetapkan pengelola berubah menjadi jalur yang dipilih oleh santri, ditindaklanjuti wawancara. Karakteristik masingmasing jalur sebagai berikut:

Table 2. Karakteristik Jalur Depan Asrama Gaza dan Depan Perumahan Ustadz

\begin{tabular}{|c|c|}
\hline $\begin{array}{c}\text { Jalur Depan Asrama } \\
\text { Gaza (ditentukan } \\
\text { pengelola) }\end{array}$ & $\begin{array}{c}\text { Jalur Depan } \\
\text { Perumahan Ustadz } \\
\text { (jalur pilihan santri) }\end{array}$ \\
\hline $\begin{array}{l}\text { - Lebar jalan cukup } \\
\text { - Cenderung kotor } \\
\text { dan ramai } \\
\text { - Tidak rapi secara } \\
\text { visual } \\
\text { - Jarak ke masjid } \\
\text { dekat } \\
\text { - Kenyamanan } \\
\text { kurang baik (udara } \\
\text { kurang segar dan } \\
\text { cenderung ada } \\
\text { rasa sumpek) }\end{array}$ & $\begin{array}{l}\text { - Jalan lebar } \\
\text { - Cenderung bersih } \\
\text { dan sepi } \\
\text { - Rapi secara visual } \\
\text { - Jarak ke masjid } \\
\text { lebih jauh } \\
\text { - Kenyamanan baik } \\
\text { (udara segar) }\end{array}$ \\
\hline
\end{tabular}

(Sumber : Dokumen Peneliti, 2018)

Santri yang menggunakan jalur depan perumahan ustadz beralasan karena suasana yang lebih nyaman, tidak ramai, dan secara visual tampak lebih bersih dan rapi, terdapat unsur estetis berupa tanaman hias di depan rumah ustadz. Sebagaimana teori perilaku, seseorang akan lebih memilih sesuatu yang membuatnya nyaman, sesuai dengan keinginan dan kebutuhanya (Hariyadi, 2010). Meskipun jalur 
depan perumahan ustadz memiliki jarak yang relatif lebih jauh daripada jalur depan asrama Gaza, santri yang mengedepankan kenyamanan, kebersihan, fleksibilitas dalam bergerak dan memiliki waktu yang lebih longgar akan memilih jalur depan perumahan ustadz.

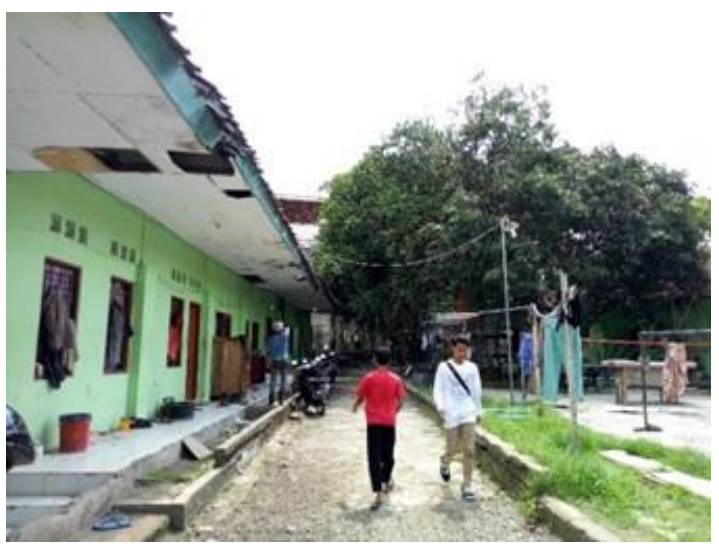

Gambar 5. Kondisi Jalur Depan Asrama Gaza (Sumber : Dokumen Peneliti, 2018)

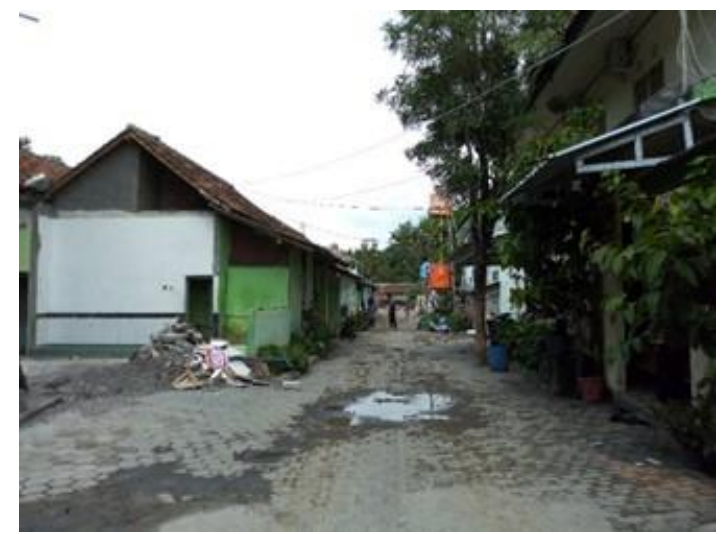

Gambar 6. Kondisi Jalur Depan Perumahan Ustadz (Sumber : Dokumen Peneliti, 2018)

Analisis berikutnya adalah analisis data berdasarkan pengamatan pada waktu siang hari yaitu pukul 13.00 WIB setelah selesai sholat dzuhur dan sore hari pukul 16.15 WIB setelah kegiatan Halaqoh Tahfizh Al Qur'an. Kegiatan santri setelah sholat dzuhur adalah makan siang. Skema awal perencanaan pola aktivitas santri adalah setelah sholat dzuhur di masjid pusat, santri kembali ke asrama untuk mengganti pakaian dari seragam sekolah menjadi pakaian keseharian lalu menuju tempat makan untuk makan siang. Pada waktu ini yang menjadi objek pengamatan kami adalah santri SW penghuni asrama Umar. Asrama ini jaraknya jauh dari masjid pusat dan tempat makan. Jika santri mengikuti skema awal perencanaan aktivitas yang diatur oleh pengelola, maka skema pola aktivitas yang terbentuk adalah garis bolak-balik dari masjid ke asrama kemudian ke tempat makan dan kembali ke asrama lagi.

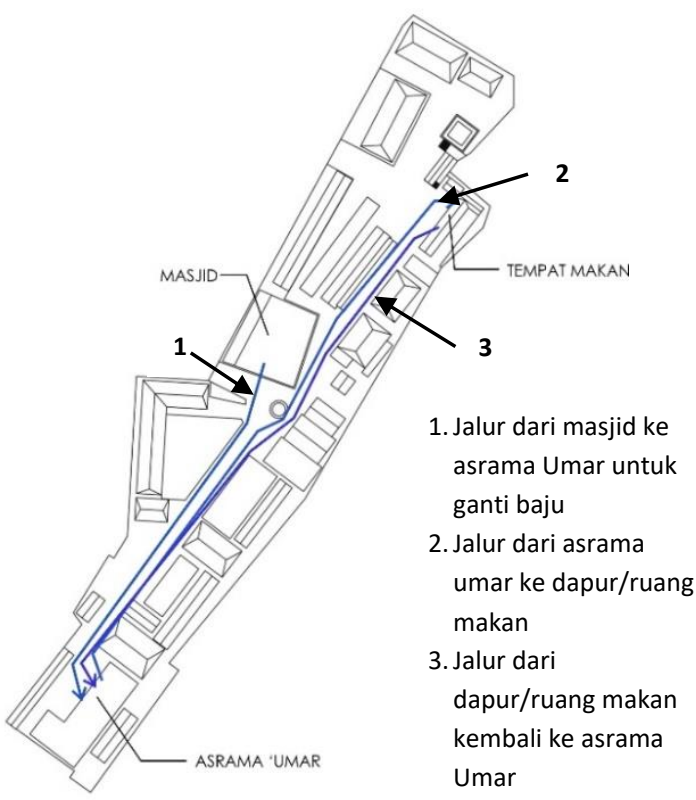

Gambar 7. Jalur sirkulasi awal berdasar aturan pengelola (Sumber : analisis peneliti, 2018)

Penelitian ini menemukan perilaku santri SW setelah sholat dzuhur, ternyata ada sebagian santri yang tidak kembali ke asrama untuk mengganti pakaian. Sebagian santri SW tersebut dari masjid pusat langsung menuju ke tempat makan.

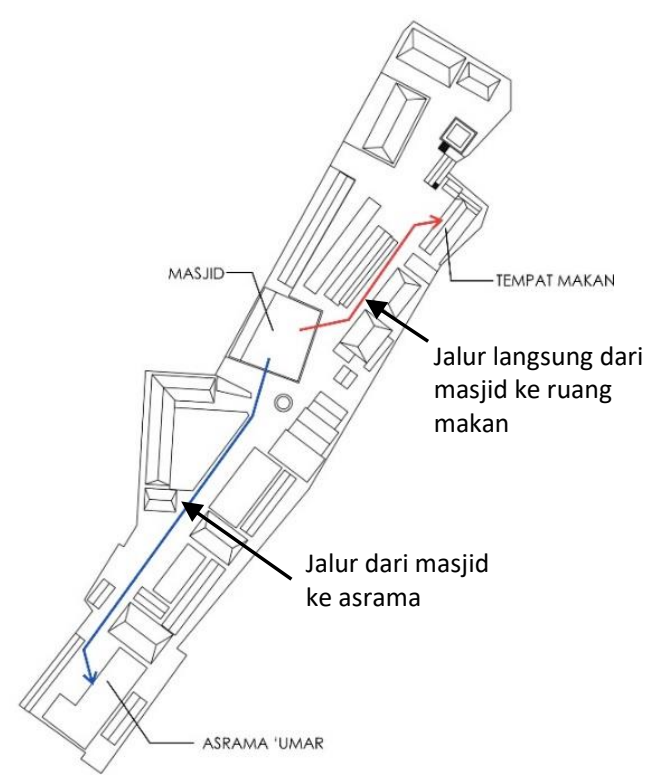

Gambar 8. Skema Aktivitas Santri SW pada Waktu Makan Siang (Sumber : analisis peneliti, 2018)

Santri beralasan apabila kembali ke asrama untuk berganti pakaian, adalah sangat tidak efisien. Jarak masjid ke asrama lebih jauh dari jarak masjid ke ruang makan. Apalagi asrama ada di sebelah selatan masjid, sedangkan ruang makan ada di sebelah utara masjid. Hal ini menjadi sangat menyusahkan bagi sebagian santri SW. 
Hal serupa terjadi pada santri MA di waktu sore hari setelah kegiatan Halaqoh Tahfizh Al Qur'an di masjid. Setelah kegiatan halaqoh selesai yaitu pada pukul 16.15 WIB kegiatan santri MA berikutnya adalah olahraga sore atau kegiatan bebas. Skema awal perencanaanya adalah setelah santri selesai halaqoh, mereka kembali ke asrama terlebih dahulu untuk mengganti pakaian olah raga, kemudian menuju lapangan untuk berolahraga atau melakukan kegiatan lainya. Perilaku santri MA yang teramati adalah sebagian besar santri MA, setelah halaqah di masjid tidak kembali ke asrama terlebih dahulu, melainkan langsung menuju ke lapangan olah raga. Sesampainya di lapangan santri tersebut melepas pakaian luar (baju sholat) dan meletakkanya tidak beraturan di pinggir lapangan atau digantung di batang pohon dekat lapangan.

Hasil wawancara kepada santri terkait alasan perilakunya, adalah karena jarak ke lapangan dari masjid lebih dekat dari pada ke asrama hunain. Oleh sebab itu santri berpendapat bahwa hanya membuang-buang waktu untuk berganti pakaian di asrama, karena waktu berolah raga adalah sangat ditunggu oleh santri untuk melepas kejenuhan sekaligus menyehatkan badan. Olah raga yang dilakukan santri adalah basket, sepak bola, volley dan sepak takraw. Kesempatan refreshing ini dimanfaatkan penuh oleh santri, sehingga santri berpendapat bahwa akan sangat sayang waktu terbuang hanya untuk berjalan dari masjid ke asrama, sementara sesungguhnya permasalahan bisa diatasi, yaitu dengan persiapan sudah membawa pakaian olah raga ketika akan halaqah di masjid.

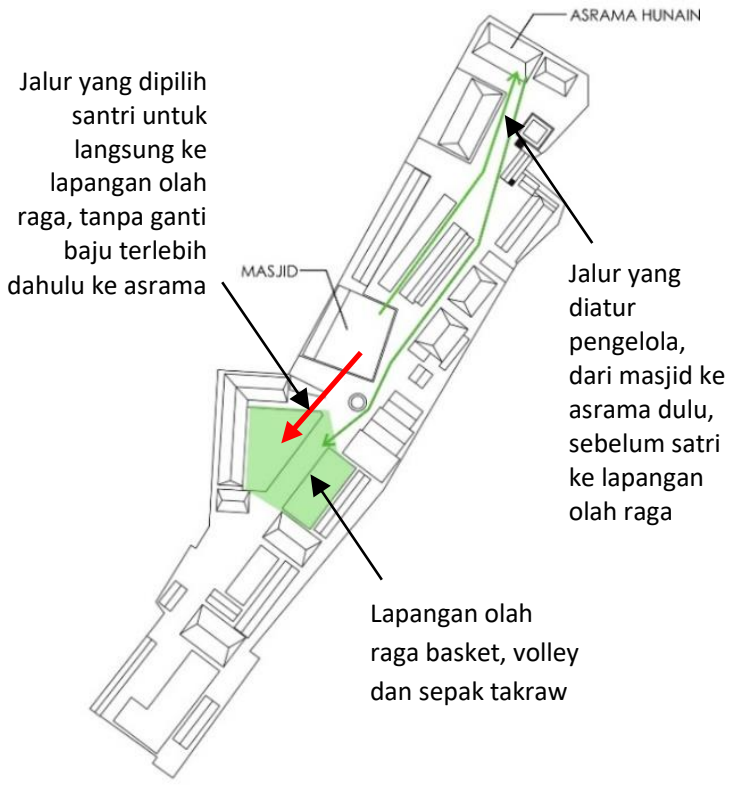

Gambar 9. Skema Jalur sirkulasi sesuai aturan antara masjid, asrama dan lapangan olah raga (Sumber : Dokumen Peneliti, 2018)
Perilaku santri dan aktivitasnya yang lebih efisien menurut santri, ternyata memberikan dampak terbentuknya kebiasaan yang kurang baik berupa tidak disiplin. Tidak semua santri membawa pakaian ganti ketika berangkat halaqah. Bagi yang membawa pakaian ganti dapat berganti pakaian olah raga ketika sampai di lapangan. Namun tidak sedikit santri yang tetap berpakaian rapi (pakaian ibadah sholat) untuk digunakan berolah raga.

Kedua kasus perilaku yang terjadi yaitu perilaku santri SW yang langsung menuju ke tempat makan tanpa kembali ke asrama untuk berganti pakaian dan perilaku santri MA yang langsung menuju ke lapangan tanpa kembali ke asrama untuk berganti pakaian juga, menunjukan bahwa sebagian santri memilih untuk menuju tempat yang mereka rasa lebih dekat dan mudah untuk dicapai untuk melakukan kegiatan berikutnya. Hal ini sesuai dengan teori perilaku di mana seseorang akan lebih memilih tempat yang lebih dekat dan mudah untuk melakukan kegiatan.

Berdasarkan kedua analisis diatas dapat dilihat bahwa penataan massa bangunan Ponpes ICBB putra berpengaruh terhadap pola aktifitas santri yang berubah dan tidak sesuai dengan pola aktivitas yang sudah diatur oleh pengelola. Tata massa Ponpes ICBB putra membuat aktivitas santri menjadi tidak efisien, sehingga santri mencari cara tersendiri agar aktivitasnya menjadi efisien.

\section{KESIMPULAN}

Kesimpulan penelitian ini adalah bahwa pola tata massa bangunan itu dapat mempengaruhi pola aktivitas seseorang, dan dalam kasus ini adalah pola tata massa Ponpes ICBB putra yang penataannya kurang efisien, mempengaruhi santri untuk mencari cara beraktivitas yang efisien menurut mereka. Para santri berusaha memenuhi kebutuhan akan kenyamanan fisik seperti udara sejuk serta kenyamanan visual seperti keindahan lingkungan, dan kebutuhan akan kelonggaran atau fleksibilitas gerak, sehingga para santri memilih jalur sirkulasi yang berbeda dari jalur yang sudah ditetapkan oleh pihak pengelola ponpes, sekalipun jalur sirkulasi tersebut lebih memakan waktu.

Hasil penelitian lain adalah bahwa petataan massa di Ponpes ICBB putra tidak efisien, sehingga mempengaruhi gerak aktivitas santri menjadi tidak efisien juga. Santri pada akhirnya mengambil keputusan untuk beraktivitas yang efisien dan mencari kemudahan, yang pada akhirnya menjadi suatu kebiasaan santri.

Manusia dan lingkungan saling mempengaruhi. Terlepas dari sifat dan karakteristik manusianya, penelitian ini menyimpulkan bahwa pola tata massa yang baik dan benar akan menciptakan pola aktivitas 
yang baik pula. Sedangkan pola tata massa yang kurang terencana dengan baik akan menciptakan pola aktivitas dan perilaku yang tidak baik pula atau tidak efisien

\section{DAFTAR PUSTAKA}

Haris, C. M. 1975. Dictionary of Architecture and Construction. New York: McGrawHill Company.

Hariyadi, B. S. 2010. Arsitektur, Lingkungan dan Perilaku. Yogyakarta: Gadjah Mada University Press.

Iswara, A. 2014. Pola Ruang, Massa, dan Sirkulasi I Archagasvara. Retrieved from anggasvara.blogspot.com:

anggasvara.blogspot.com/2014/06/bab-ipendahuluan-1.html

Sofyan, D. A. 2010. Jenis-jenis Sirkulasi. Retrieved from dedenasepsofyan.blogspot.com: http://dedenasepsofyan.blogspot.com/2010/02/j enis-jenis-pola-sirkulasi.html

Tofani, L. 2011. Laporan Tugas Akhir Terminal Imbanagara Kabupaten Ciamis. Fakultas Teknik dan Ilmu Komputer: Universitas Komputer Indonesia.

Yadnya, D. 2012. Konsep Perancangan Tapak. Denpasar: tidak diterbitkan. 